PALAVRAS. Revista de Epistemología, Metodología y Ética del Psicoanálisis ISSN: 2468-9831

www.revistas.unlp.edu.ar/palavras

palavras@outlook.com.ar

Argentina

\title{
LOS LAZOS DE AMOR: VIOLENCIA RACIONAL Y DOMINACIÓN ERÓTICA
}

DOI $10.24215 / 24689831 \mathrm{e} 018$

Jessica Benjamin

\section{Cómo citar este artículo:}

Benjamin, J. (2017). Lazos de amor: violencia racional y erótica (Ariel Martínez, trad.). Palauras. Revista de Epistemología, Metodología y Ética del Psicoanálisis, 3, 46-86. Recuperado de www.revistas.unlp.edu.ar/palavras (Obra original publicada en 1980). 


\section{LOS LAZOS DE AMOR: VIOLENCIA RACIONAL Y DOMINACIÓN ERÓTICA}

Autor: Jessica Benjamin

Traducción: Ariel Martínez ${ }^{1} *$

Título original: "The bonds of love: Rational violence and erotic domination". Publicado en Feminist Studies, 6(1), 144-174.

\section{Introducción}

Este ensayo se ocupa de la violencia -la violencia de la dominación erótica. Se trata de la extraña unión entre racionalidad y violencia que se forja en el corazón secreto de nuestra cultura y sólo a veces es actuada en el cuerpo. Esta unión ha inspirado a algunas de las imágenes más sagradas de trascendencia religiosa y ahora sale a la luz en el porno de los puestos de revistas. La imagen de la violación femenina, de la dominación erótica, es un objeto de temor y odio, incluso cuando no se la considere directamente responsable de la degradación y el ataque a las mujeres. Mi preocupación no es tanto la flagrante victimización, el odio y el abuso, como la fantasía de violencia racional. La fantasía aparece como un tema vital de la imaginación pornográfica contemporánea donde las mujeres son regularmente representadas en lazos del amor. Pero el esclavo del amor, no es siempre una mujer o sólo alguien heterosexual; La fantasía de la dominación erótica impregna toda la imaginación sexual en nuestra cultura. Esta fantasía, que mezcla amor, control y sumisión, también fluye bajo la superficie del "amor normal" entre adultos. Pero espero mostrar cómo sus orígenes se encuentran en la experiencia de la primera infancia, cargada de anhelo por, y negación del, reconocimiento mutuo. Para llegar a ser seres humanos, tenemos que recibir reconocimiento de las primeras personas que nos cuidan. En nuestra sociedad es generalmente la madre quien otorgada el reconocimiento. Ella es la que responde a nuestras

\footnotetext{
${ }^{1}$ * CONICET - Universidad Nacional de La Plata, Argentina. Mail: arieles21@hotmail.com
} 
comunicaciones, nuestros actos y nuestros gestos, de modo que sentimos que son significativos. Su reconocimiento nos hace sentir esa conexión vital con otro ser que es tan necesaria para la supervivencia humana como el alimento. Esta situación psicológica o social, esta entrega de alimento, es tan evidentemente esencial para la maternidad que estamos tentados de hacer de la crianza y la maternidad sinónimos. Pero las feministas han llegado a sospechar sobre la restricción que la nutrición impone a la maternidad y la restricción que la maternidad impone a las mujeres. Hemos estado explorando las repercusiones psicológicas de la maternidad de las mujeres y de la degradación de la crianza en nuestra cultura ${ }^{2}$ ¿ ¿Por qué es algo tan necesario para la supervivencia y el desarrollo del individuo repudiar y devaluar a la madre? ¿Por qué la nutrición es contraproducente para quien la proporciona? ¿Cómo esta primera experiencia de lucha por el reconocimiento contribuye a la negación de la mutualidad, a la relación de dominación entre el varón y la mujer?

Para responder a estas preguntas, las escritoras feministas han comenzado a examinar el complicado proceso por el cual los seres humanos son socializados a la luz de las teorías psicológicas del yo. En la mayoría de las familias occidentales, el individuo adquiere un yo, o sentido de la identidad, contra el trasfondo de una presencia materna individual. En términos psicológicos, el

\footnotetext{
${ }^{2}$ Me refiero aquí a la matriz de pensamiento que ha abordado la cuestión de la maternidad de las mujeres, incluyendo, sobre todo, el trabajo de Nancy Chodorow, The Reproduction of Mothering: Psychoanalysis and the Sociology of Gender (Berkeley: University of California Press, 1978); Dorothy Dinnerstein, The Mermaid and the Minotaur: Sexual Arrangements and Human Malaise (New York: Harper and Row, 1976); y Adrienne Rich, Of Woman Born: Motherhood as Experience and Institution (New York: W. W. Norton, 1976). Véase también a Jessie Bernard, The Future of Motherhood (New York: Dial Press, 1974) para una sintesis de la numerosa literatura relevante. El pensamiento de Chodorow ha sido especialmente importante para mí, porque me sugirió la exploración de la teoría de las relaciones de objeto, una tendencia en el pensamiento psicoanalítico en la que me referencio significativamente. El marco teórico más amplio que contribuye a mi análisis es la teoría crítica de la escuela Frankfurt. Para una discusión de su importancia para el feminismo, véase Jessica Benjamin, "Authority and the Family Revisited; or, A World Without Fathers", New German Critique 4, no. 3 (Winter 1978): 35-57. Los comentarios de Evelyn Keller y Jane Lazarre también fueron particularmente útiles en la formulación de este documento, al igual que las sugerencias editoriales de Hester Eisenstein. El artículo fue entregado en The Scholar and the Feminist VI Conference (Barnard College) sobre The Future of Difference, Abril de 1979.
} 
niño pequeño empieza a diferenciarse del medio, que consiste en la madre más los objetos infundidos por su presencia. La mayoría de las teorias basadas en Freud subrayan que el niño crece a partir de un sentido original de unidad con el mundo-madre en un doloroso sentido de su propia separatividad. El niño está dividido entre el deseo de volver a aquella unidad y el deseo de convertirse en una persona autónoma. Él o ella viene a darse cuenta de la diferencia entre uno mismo y otro de dos maneras: distinguiendo al yo del medio (no-yo), y descubriendo su propia identidad. Margaret Mahler denominó estos dos aspectos de la diferenciación como separación e individuación, respectivamente ${ }^{3}$.

El conflicto más familiar que surge de la diferenciación es entre la necesidad de establecer una identidad autónoma y la necesidad de ser reconocido por otro. Son precisamente los actos independientes los que requieren reconocimiento y así reafirman su dependencia. A la luz de la relación temprana entre el niño y la madre en la que la contradicción se experimenta primero, me ocuparé de tres cuestiones. La primera es cómo la separación y el reconocimiento que surgen en el curso de la diferenciación reaparecen en otras relaciones de dominación, especialmente la dominación erótica. La segunda, es cómo las diferentes formas en que las mujeres y los hombres se relacionan y diferencian de su madre influye en los roles que ellos juegan en tales relaciones. Por último, la tercera cuestión es la manera en que la experiencia masculina de diferenciación está vinculada a una forma de racionalidad que impregna nuestra cultura y resulta esencial para el sadomasoquismo. Este último fenómeno es lo que yo llamo violencia racional.

Este análisis probablemente no es aplicable a todas las formas de violencia, o incluso a toda la violencia masculina contra las mujeres, a pesar de que las

\footnotetext{
${ }^{3}$ Margaret Mahler, Fred Pine, and Anni Bergman, The Psychological Birth of the Human Infant (New York: Basic Books, 1975). Probablemente, más que cualquier otra escritora contemporánea, el trabajo de Mahler es el que más profundamente ha influenciado al pensamiento psicoanalítico sobre la infancia $y$ ha alcanzado ampliamente audiencias populares. Sin embargo, muchos otros investigadores en el campo de la infancia no comparten su posición.
} 
motivaciones de los hombres para la violación y agresión pueden ser similares a las que aparecen en la violencia racional. Las cuestiones de control y posesión, el repudio violento y la humillación de las mujeres, deben jugar ciertamente un papel. Pero limito mi estudio a la forma controlada y ritualizada de violencia que se expresa en la vida de la fantasía sexual y en algunas prácticas sexuales cuidadosamente institucionalizadas. Hay un gran número de otras formas de violencia contra las mujeres que no participan en este carácter racional, en las que las mujeres simplemente son asaltadas y no pueden defenderse con éxito. El peligro es que incluso en tales casos las mujeres se censuran a sí mismas y se sienten culpables por enjuiciar al agresor ${ }^{4}$. Esto hace que el tema de la violencia racional o la dominación erótica, donde la participación es voluntaria o sólo una fantasía, parezca para algunos una sutil justificación de toda forma de violencia masculina. Sin embargo, comprender las fuentes de la violencia debe distinguirse de culpar a la víctima. La relación entre la fantasía y los actos reales, entre la imaginación pornográfica y la perpetuación de violencia, debe ser estudiada empíricamente.

Mi preocupación aquí es simplemente examinar las cuestiones psicológicas que subyacen a la dominación a través del amor, la fantasía mutua de control y sumisión que conocemos como sadomasoquismo. Mis datos no se han extraído de estudios sobre prácticas sadomasoquistas, sino de un solo y poderoso estudio de la imaginación erótica, The Story of $\mathrm{O}$ de Paulina Réage ${ }^{5}$. Por lo tanto, estas especulaciones bastante esquemáticas no deben tomarse como

\footnotetext{
${ }^{4}$ Sobre violación, véase Susan Brownmiller, Against Our Will: Men, Women and Rape (New York: Simon and Schuster, 1975).

${ }^{5}$ Pauline Reage, The Story of O, traducido por S. d'Estree (New York: Grove Press, 1965). En cuanto a la mayor relevancia de este estudio para la imaginación pornográfica o la fantasía sadomasoquista, el mejor testimonio es probablemente el poder del texto y el reconocimiento excesivamente amplio que recibió. De hecho, los críticos feministas a veces han confundido The Story of $O$ con una afirmación de la degradación femenina; véase, por ejemplo, Andrea Dworkin, "Woman as Victim: Story of O", Feminist Studies 2, no. 1 (1974): 107-111. También contribuye, Nine and a Half Weeks de Elizabeth McNeill (New York: Dutton, 1978), un relato de temática sadomasoquista ostensiblemente auténtico escrito por la mujer participante, describe una especie de dependencia psíquica servil asombrosamente similar a la de 'O'.
} 
conclusiones. Mi objetivo es sugerir una explicación para la asignación y caracterización de roles femeninos y masculinos en la fantasía sadomasoquista, basada en el diferente modo en que los niños y las niñas se diferencian. El grado en que varones y mujeres de hecho se identifican con tales roles es una cuestión empírica. Es evidente que estos roles no son siempre jugados por un solo sexo, ya no son asignados necesariamente a un género -aun cuando todavía estén asociados a él. Sin embargo, la fantasía de la sumisión y el control racional se perpetúa por la división de las dos posturas básicas, femenina y masculina, en diferenciación. Una postura, tradicionalmente masculina, exagera los límites propios y la otra postura, tradicionalmente femenina, exagera la renuncia del yo. La división de estas posturas es el límite más importante de todos.

\section{Diferenciación y racionalidad masculina}

Al explicar la diferenciación, las primeras teorías psicoanalíticas revelaron un sesgo peculiar que la observación empírica de los infantes podría corregir con bastante facilidad. (Hay excepciones notables, a las cuales llegaremos más adelante). El niño fue concebido como inicialmente desinteresado en el mundo y completamente inconsciente de la existencia del otro. Esta teoría, entonces, enfatizó el proceso de ruptura con la unidad, separándose del otro. No vio que el descubrimiento del yo y el descubrimiento del otro realmente van de la mano, que la conciencia del yo y la conciencia del otro se desarrollan como procesos interdependientes. En cambio, esta teoría situaba las funciones mutuas de reconocer al otro y de establecer su propia identidad autónoma en oposición. Veía al niño como atado a la madre a través de la dependencia fisiológica, en lugar de verlo como específicamente atraído a ella como el otro ser social que él o ella llega a conocer mejor. La perspectiva de que el niño experimenta a la madre como un instrumento de sus propias necesidades corresponde con la devaluación de la necesidad de un niño de reconocer a la madre como un ser o sujeto independiente con sus propias necesidades. Dentro de este marco teórico, parece natural que el niño vea a la madre como un objeto y así logre 
subjetivarse abandonándola en lugar de descubrirla. El énfasis está en el establecimiento de la separación y los límites, más que en el reconocimiento mutuo de los sujetos.

Nancy Chodorow ha demostrado cómo estos problemas en las versiones psicoanalíticas de la diferenciación están conectados con una exageración de la "diferencia", que refleja la experiencia masculina. Los hijos varones logran su identidad distintiva repudiando (más o menos violentamente) a la madre. Inicialmente, todos los bebés no sólo aman a sus madres, sino que también se identifican y desean emularlas. Pero los niños descubren que no pueden ser, ni convertirse en ella; sólo pueden tenerla. Cuando crezcan, serán independientes e indiferentes a la madre, mientras que las niñas logran la independencia con la expectativa de que seguirán siendo como ella 6 . Este repudio de la madre por los varones también ha significado que ella no es reconocida como una persona independiente, como otro sujeto, sino como algo Otro: como naturaleza, como instrumento u objeto, como menos-que-humana ${ }^{7}$. La independencia del hijo varón se compra al precio de decir: ¡No soy en nada como ella, quien me atiende y me cuida! Yo soy alguien reconocido y alimentado, no quien reconoce y cuida. Así, la identidad masculina hace hincapié en la diferencia del cuidador sobre la mismidad y en la separación de la madre sobre la individuación. Se basa en la donación o adopción unilateral, en lugar de la reciprocidad. Para los niños pequeños, ese aspecto de la diferenciación que implica descubrir el yo de la otra persona se reduce a establecer disimilitud y diferencia con la madre. No es de

${ }^{6}$ Nancy Chodorow, "Difference, Relation and Gender in Psychoanalytic Perspective", Socialist Review 9, no. 4 (July-August 1979): 51-70. También véase Chodorow, Reproduction of Mothering, y Evelyn Fox Keller, "Gender and Science", Psychoanalysis and Contemgorary Thought 1, no. 3 (1978): 409-53.

${ }^{7}$ La formulación de Simone de Beauvoir de la mujer como lo Otro, en The Second Sex (New York: Vintage, 1974) obviamente es el punto de partida crucial para el análisis de la relación sujeto-otro, ya que se aplica a mujeres y varones. Aunque su trabajo ha influenciado fuertemente este ensayo, no utilizo necesariamente su concepto de la alteridad cuando aquí utilizo el término "otro". De Beauvoir lo utiliza para referirse a la exclusión, rechazo y objetivación de la mujer por parte de los varones, y yo la utilizo para referirme más generalmente a la hipotética confrontación del yo con otro sujeto, que puede o no incluir estos elementos. 
extrañar entonces que la mayoría de las teorias del desarrollo psicológico hayan sido en gran medida incapaces de mantener (incluso en el pensamiento) la tensión simultánea entre igualdad y diferencia. Reflejan la experiencia masculina de que la identidad independiente sólo puede ser ganada a partir de desaprender la identificación con la madre.

La mayoría de las teorías también reflejan el hecho de que convertirse en alguien como la madre, como lo hacen las niñas, probablemente significará el sacrificio de la subjetividad o la individualidad independiente. Significará subordinación a los demás y a sus necesidades. En la medida en que lo hace, la niña tiene principalmente que identificarse con su padre, con la postura masculina de diferencias enfáticas, porque la madre no es una figura independiente. Generalmente, sin embargo, la postura femenina es lo opuesto de la masculina -fusión a expensas de individualidad. La experiencia de la niña pequeña nos muestra, a menudo, el modo en que ella desarrolla la continuidad y la igualdad a expensas de la diferencia y la independencia ${ }^{8}$. Para ella, el mandato es: debo ser como ella que me atiende y me cuida. La tentación de ser indiferenciada, de desestimar los limites, se refuerza para ella como una forma apropiada de subjetividad. Ella es capaz de reconocer la subjetividad del otro, pero -como madre- no espera ser tratada como un sujeto independiente. La negación de las mujeres de su propia subjetividad corresponde a la percepción masculina de la madre. En su propia mente ella se convierte en objeto, instrumento, madre tierra. Así ella sirve a los hombres como su Otro, su contraparte, el lado de sí mismos que reprimen.

Cada género es capaz de representar sólo un aspecto de la relación de uno mismo-otro, ya sea fusionándose o separándose, y cada género desempeña un papel en un todo polarizado. Pero ninguno alcanza verdadera independencia. Pues incluso la postura masculina de alcanzar la independencia negando a la madre es una postura defensiva: el énfasis excesivo en las fronteras entre yo y

8 Jane Flax, "The Conflict Between Nurturance and Autonomy in Mother-Daughter Relationships and Within Feminism," Feminist Studies 4, no. 2 (June 1978): 171-91. Argumenta que las madres se identifican más fuertemente con sus hijas y así inhiben su separación. 
no-yo significa que la individualidad se define negativamente como la separación de los demás ${ }^{9}$.

La pregunta que he considerado desde hace algún tiempo es cómo el énfasis en los límites de la identidad masculina está conectado con la hegemonía masculina en la cultura. He buscado un vínculo entre la racionalidad como una actitud mental "masculina" y la racionalidad como una tendencia penetrante en la cultura como un todo. Evelyn Keller ha sugerido un vínculo entre la manera en que los varones se diferencian y su desarrollo como un acercamiento científico u objetivo al mundo ${ }^{10}$. El tipo de diferenciación que he descrito como masculino parece corresponder a la visión racional del mundo occidental, en la "racionalidad masculina"11. Esta visión del mundo enfatiza la diferencia sobre la mismidad, los límites sobre la fluidez. Concibe como vehículos de crecimiento la polaridad y la oposición en lugar de mutualidad e interdependencia. Es decir, no tolera la experiencia simultánea de impulsos contradictorios: la ambivalencia. Por último, esta visión del mundo no otorga a la otra persona el estatus de otro sujeto, sino sólo el de un objeto. Por extensión, este estatus de objeto se concede al mundo entero, que desde sus inicios fue infundido con la presencia de la madre. En estas tendencias psíquicas, los elementos básicos de la racionalidad occidental toman forma: análisis o diferenciación; dualidad o polaridad; y objetividad. En esta línea, Keller ha argumentado que la

\footnotetext{
${ }^{9}$ Chodorow, "Difference, Relation and Gender".

${ }^{10}$ Keller, "Gender and Science".

${ }^{11}$ Esto no pretende ser un modelo causal en el que las disposiciones psíquicas produzcan condiciones sociales. Estoy asumiendo una relación entre las condiciones sociales y culturales de la maternidad y la forma en que los niños se diferencian, entre los conflictos específicos de la experiencia de la diferenciación y la mentalidad o visión del mundo de las personas en una cultura determinada. Sin embargo, no estoy proponiendo un esquema para estas relaciones; por ejemplo, que exista una línea causal que comienza en las relaciones de producción, se traslada a las relaciones de reproducción, a prácticas de socialización particulares, culminando finalmente en un tipo particular de personalidad. Más bien quiero identificar ciertos temas o conflictos que se repiten en diferentes niveles de organización social, experiencias y relaciones. En este caso, me interesa el tema de la racionalidad y los conflictos en torno a la autonomía y el reconocimiento.
} 
experiencia más temprana del niño de convertirse en un individuo ha pavimentado el camino para un pensamiento que "está basado en una dicotomía radical entre sujeto y objeto"12. Esta es la dicotomía que, en la ciencia y en otras creaciones racionales, niega el reconocimiento mutuo de los sujetos.

La mente racional, entonces, se deriva de una experiencia unilateral de la diferenciación -una experiencia que obtura la realidad del otro. El hecho de que el sujeto se distingue de, y en oposición a, el objeto significa que el dador de los cuidados y el reconocimiento está radicalmente alejado de quien lo recibe. Quien recibe no puede, o ya no puede, imaginarse a sí mismo en la posición de dador. Este fracaso de la imaginación se convierte en el gran obstáculo de la reciprocidad emocional (por ejemplo en la vida adulta, donde algunos no se pueden entregar y otros no pueden dar). Por supuesto, los niños son capaces de entregarse y reconocer a sus madres, tal vez mucho más de lo que se les permite. Existe documentación considerable sobre la interacción recíproca entre madres e infantes. En algún momento, sin embargo, esta reciprocidad es probablemente interferida por las vicisitudes de la identificación y de la diferenciación de género. Lo que vemos es el resultado: la madre generalmente no es apreciada por su hijo como una persona separada. El niño es capaz de independizarse mediante la adopción de la postura masculina de repudiar la identificación con la madre, negándose a reconocerla, objetivándola.

La diferenciación que se produce sin apreciación de la subjetividad de la madre es perfectamente consonante con el desarrollo de las facultades racionales. De hecho, parece acelerarlo. El individuo es capaz de distinguirse cognitivamente a sí mismo de otro. La persona sabe que, él o ella, es fisica y mentalmente distinta y capaz de actuar, socialmente, como si las otras personas fueran sujetos. Pero en el nivel más profundo del sentimiento no hay ese sentido agudo y claro, esa vitalidad vibrante, de saber que yo soy yo y que tú eres tú. Racionalmente o cognitivamente, la distinción es clara; emocional e

\footnotetext{
${ }^{12}$ Keller, "Gender and Science", p. 424.
} 
inconscientemente, la otra persona es experimentada simplemente como la proyección de una imagen mental. La otra persona no existe por propio derecho, y por lo tanto la sensación de vitalidad que podría emanar de la interacción mutua con ella o él es disminuida. Es sólo "como si" ella o él estuviera allí, mientras que debajo se siente solo. Como lo expresó el científico masculino en la historia de Christa Wolf, él siempre se siente "como en el cine"13. Esta incapacidad de experimentar a los demás como reales, y concomitantemente al yo como real, es bien conocida por los clínicos de hoy. Este sentimiento de irrealidad es el resultado de una diferenciación unilateral o (como yo lo pienso) una "diferenciación falsa"14. La racionalidad como substitutos para el reconocimiento amenaza con destruir el sentido de realidad y de identidad que se suponía que debía crear.

En resumen, tanto en la teoría como en la práctica, nuestra cultura sólo conoce una forma de individualidad: la postura masculina de sobre-diferenciación, de separación y negación de las tendencias hacia la mismidad, la fusión y la respuesta recíproca. En esta "falsa diferenciación" el otro sujeto sigue siendo un objeto, en lugar de emerger como una persona en su propio derecho. Esta forma de establecer y proteger la individualidad encaja con la postura dualista y objetiva de la racionalidad occidental. Ser mujer implica estar excluida de este individualismo racional, ser un objeto de él o una amenaza para él. Ser un varón no es meramente afirmar un lado de la dualidad, la supremacía del sujeto racional. También es insistir en que el dualismo, la división y los límites

\footnotetext{
${ }^{13}$ Christa Wolf, "Self-Experiment", New German Critique, no. 13 (Winter 1978): 109-32. En esta historia, una mujer científica experimenta un cambio de sexo. Cuando su jefe, el principal investigador, le pregunta cómo se siente ahora que es un hombre, da una contestación contundente. Su respuesta, impactante, es "i¿y vos?!"

14 Este síndrome, en el que la diferenciación se logra sólo a nivel cognitivo y consciente, ocultando un sentido desesperado de que nadie está realmente "allí", probablemente ha sido mejor descrito y discutido por R. D. Laing, en The Divided Self (Middlesex: Penguin, 1969). Laing señala que cierto monto de despersonalización, es decir, tratar al otro como un "robot androide" en lugar de otro sujeto; se considera normal y deseable en nuestra cultura (p.47). Los trastornos narcisistas graves, que están recibiendo cada vez más atención entre los clínicos, también implican una incapacidad para experimentar a los demás como algo más que objetos manipulables o resistentes en el mundo del yo.
} 
entre las posturas masculina y femenina se mantienen. Veremos cómo estas relaciones específicas de género tradicionales vinculadas con las fronteras se repiten en el patrón de la dominación erótica.

\section{Dominación erótica: amo y esclavo en Hegel y Bataille}

Psicológicamente, la postura racional puede promover una forma extrema de individuación, una rigidez de las fronteras entre el yo y el otro, que son insoportablemente aislantes. Ningún sujeto puede realmente desenredarse a sí mismo/a de la dependencia de otros sujetos, de su necesidad de reconocimiento. El sujeto aislado busca la protección de esta dependencia. Para separarse sin estar solo, niega la separación del otro y trata de resolver el problema de la dependencia poseyendo o controlando al otro. Así como él o ella busca ser diferente e individual reduciendo a la otra persona a un objeto, él o ella busca la autonomía dominando a la otra persona.

La dominación contiene la amenaza o la posibilidad de violencia contra el otro. La violencia se basa en la negación de la subjetividad independiente de la otra persona y en la negación de su autonomía. La violencia es también una manera de expresar o afirmar el control sobre el otro, de establecer la propia frontera y negar la de la otra persona. Como las otras formas de falsa diferenciación, la violencia es una forma particularmente apta para la afirmación de la identidad masculina. Es una forma de repudiar la mismidad, la dependencia y la cercanía con otra persona, al mismo tiempo que intenta evitar los sentimientos de soledad que de alli se derivan. Uno hace al otro un objeto, pero conserva su posesión. En este sentido, la violencia también es un intento de resolver los problemas de la autonomía y el reconocimiento, negando la subjetividad del otro y su propia identificación con él o ella.

La violencia, como la racionalidad, sólo intensifica las contradicciones de la dependencia. Hegel, en The Phenomenology of Spirit, formuló la clásica declaración sobre el dilema de la inevitable dependencia del sujeto con otra persona para el reconocimiento. Como será evidente, la formulación de Hegel refleja el conocimiento implícito de una idea que los psicólogos han articulado 
recientemente. La propia autonomía se desarrolla, y se confirma más tarde, principalmente por el sentido de ser capaz de afectar a otros con nuestros actos. Esta confirmación, especialmente en la primera relación, nos permite desarrollar una apreciación de la subjetividad de los demás. El efecto que tenemos en algo o alguien es una forma de confirmar nuestra realidad. Si nuestros actos no tienen efecto sobre el otro, o si el otro se niega a reconocer nuestro acto, nos sentimos impotentes. Pero si actuamos de tal manera en que la otra persona es completamente negada, no hay nadie allí que nos reconozca. Por lo tanto, es necesario que, cuando afectamos a otro, él o ella no se disuelva simplemente bajo el impacto de nuestras acciones. El otro debe mantener simultáneamente su integridad, así como su afectación.

Así, por ejemplo, si la madre no impone límites al niño, y si, en efecto, se oblitera a sí misma y a sus propios intereses y se deja controlar por completo, deja de desempeñar el papel del otro. Es esta auto-obliteración por parte de la instancia parental "permisiva" lo que hace que el niño que "obtiene todo lo que quiere" sea tan poco feliz. La instancia parental deja de ser otro sujeto que puede reconocer las intenciones y acciones del niño, y el niño es abandonado ${ }^{15}$. Él o ella se convierte simplemente en un objeto, una cosa y ya no existe fuera del yo. Lo que estoy describiendo aquí es una dialéctica de control: si controlo completamente al otro, entonces el otro deja de existir, y si el otro me controla completamente, dejo de existir. La verdadera diferenciación significa mantener la tensión esencial de los impulsos contradictorios, negar y reconocer.

\footnotetext{
${ }^{15}$ Una variedad de psicólogos y psicoanalistas abrazan esta visión de cómo se desarrolla la individualidad. Por ejemplo, los desarrollistas se refieren a un sentido de efectividad o de eficacia. Véase R. Schaffer, Mothering (Cambridge: Harvard University Press, 1977); y M. D. S. Ainsworth y S. M. Bell, "Mother-Infant Interaction and the Development of Competence," en The Growth of Competence, ed. K. Connelly and Jerome Bruner (New York: Academic Press, 1974), pp. 97-118. El psicoanalista D. W. Winnicott escribe sobre el reconocimiento parental de los "gestos espontáneos" del bebé en "Ego Distortion in Terms of True and False Self?', en Maturational Processes and the Facilitating Environment (New York: International Universities Press, 1965), pp. 140-52. Para una declaración más completa sobre la necesidad de reconocer su sentido de agencia y autoría, véase Jessica Benjamin, Internalization and Instrumental Culture: A Reinterpretation of Psychoanalysis and Social Theory (Ph.D. diss., New York University, 1978).
} 
La discusión de Hegel sobre la relación amo-esclavo ${ }^{16}$ explica cómo la necesidad de reconocimiento por otro sujeto se convierte en un vehículo de dominación. Las dos relaciones básicas con otro (sujeto) son el reconocimiento y la negación. Cada acción que realiza el sujeto en un objeto lo niega. Es decir, cambia al objeto de modo que ya no es sino algo distinto de lo que era. Al actuar sobre las cosas las cambiamos; al transformarlas, estamos negando su forma previa. Si tratamos de controlarlo absolutamente, estamos quitando su forma como cosa que existe independiente. Por lo tanto, lo estamos negando completamente. Si continúan sobreviviendo, no impermeables a nuestro acto, sino que todavía se reconocen ellos mismos en su forma alterada, no son completamente negados. Al conservar su identidad a lo largo de ser diferentes, se demuestran ser sujetos conscientes de sí mismos, "yo soy como yo". Porque yo soy yo, sé que yo soy, incluso cuando cambio. Por el contrario, una cosa no conserva su identidad a través del cambio. Puede ser completamente consumido y destruido por mí, o puede permanecer sin ser afectado. No es capaz, como otro sujeto, de ser negado por mí ni de reconocerme.

En suma, Hegel está diciendo que, al desear al otro, queremos ser reconocidos por el otro. Tratamos de realizar este deseo en un acto, pero si este acto destruye por completo al otro, el otro no puede reconocernos. Si consume al otro, dejándolo sin consciencia, nos convertimos en la incorporación, encarnación de esta cosa muerta o sin conciencia. Para estar vivos en relación con otro, son necesarias dos cosas: debemos actuar de tal manera que no negemos completamente al otro; y el deseo en nuestro acto debe ser reconocido por el otro. Por eso, para volver a la idea de la verdadera diferenciación, es necesario contar simultáneamente con la negación y con el reconocimiento entre el yo y el otro. Simplemente separar y afirmar la diferencia es negar al

${ }^{16}$ G.W . F. Hegel", The Independence and Dependence of Self-Consciousness: Master and Slave", chap. 4. A., The Phenomenology of Spirit (Hamburg: Felix Meiner, 1952), pp. 141-50. Al utilizar Hegel para tal análisis, estoy por supuesto permitiéndome la libertad de interpretar imprecisamente. Mi uso está influenciado por Introduction to the Reading of Hegel de Alexandre Kojeve (New York: Basic Books, 1969), especialmente el cap. 1. 
otro, de manera que él o ella no puede satisfacer plenamente la necesidad del yo de reconocimiento.

La discusión de Hegel sobre la dominación comienza con dos sujetos enfrentados entre sí en la lucha por el reconocimiento. Para ganar el reconocimiento y negar al otro, el sujeto se arriesga a morir. Pero si el sujeto mata al otro, él o ella permanece una vez más solo y esclaviza y subyuga al otro. ¿Por qué el amo escoge la dominación sobre la mutualidad y la reciprocidad? Esta elección no es más problemática para Hegel que para Freud. El yo naciente quiere ser omnipotente, o mejor dicho, tiene la fantasía de que su proceso mental es idéntico al mundo. La omnipotencia subsiguiente es vista como una regresión a esta primera etapa necesaria ${ }^{17}$. Lo que Hegel dice es que la autoconsciencia quiere ser absoluta; quiere ser reconocida por el otro, para situarse en el mundo real, es decir, probar que existe objetivamente. El yo quiere demostrar esto a expensas del otro. El yo quiere creerse el único, el mundo entero; abjura la dependencia. El yo quiere ser uno y todo solo, negar todo lo demás. Empieza por incorporar todo lo demás, permitiendo que el otro exista sólo como un objeto dentro de sí mismo, en otras palabras, como un objeto mental. Quiere controlar todo lo que importa, como dijo Dorothy Dinnerstein. Así pues, para estos pensadores, el yo sólo renuncia a esta omnipotencia cuando realiza su dependencia -en Freud, a través del deseo animal o de la necesidad fisiológica, en Hegel, a través del deseo de reconocimiento. El sujeto descubre que si devora por completo al otro (en el nivel animal) o controla al otro (a nivel humano), ya no puede obtener lo que quería del otro. Así que hace algo mejor. Pero aunque el sujeto puede renunciar al deseo de controlar o devorar al otro completamente, lo hace sólo por interés

\footnotetext{
${ }^{17}$ Esta idea de una etapa primitiva y mágica del pensamiento, que corresponde a la experiencia de la "omnipotencia de pensamientos", fue desarrollada por Freud como una elaboración posterior de su concepto de narcisismo (es decir, que el yo es primero indiferente y luego hostil al mundo exterior), tal como se definió en el ensayo de 1915,"Instincts and Their Vicissitudes", en Sigmund Freud, General Psychological Theory, ed. P. Reiff (New York: Macmillan, Collier, 1963), pp. 83-103. A esto suele referirse generalmente como narcisismo primario. Mahler postula que inicialmente el niño está en un estado de absoluto narcisismo primario o "autismo normal" (Mahler, Pine, and Bergman, Psychological Birth, p. 42).
} 
propio. Esto está lejos de una apreciación real del derecho del otro de existir como persona en su propio derecho.

Por supuesto, Hegel reconoce brevemente la posibilidad de reconocimiento mutuo entre sujetos en los que ambos participan de los elementos contradictorios de la negación y el reconocimiento. Pero la polarización de estos dos momentos, uno contra el otro, constituye una parte necesaria de la dialéctica. Así, en el esquema de Hegel, cada sujeto termina encarnando sólo un momento. Psicoanalíticamente hablando, este desglose de la totalidad se llama fraccionamiento. La totalidad de cada uno sólo puede existir si se mantiene la contradicción o la tensión. Pero de alguna manera está en la naturaleza de este vínculo que la tensión se rompa, y el todo se divida en mitades opuestas.

¿Cómo explicamos esta división aparentemente inevitable? ¿Por una intolerancia esencial de la contradicción? ¿Por el hecho de que el movimiento o cambio sólo puede ocurrir a través de la dialéctica de la división y la reunificación? Aunque la respuesta a esta pregunta hasta ahora nos excede, es evidente que cuando los dos polos de la unidad se dividen, surge la relación de dominación. Un miembro de la relación desea y niega, mientras que el otro sólo reconoce. La relación amo-esclavo puede ser comprendida como un fracaso de la diferenciación y de la integridad -la pérdida de la tensión esencial.

Georges Bataille fue el primero en usar el análisis hegeliano de la relación entre el amo y el esclavo para comprender el erotismo, o la violación sexual ${ }^{18}$. Bataille centra su tratamiento de la dialéctica hegeliana entre el yo y el otro en torno al problema por mantener la tensión entre la vida y la muerte. Cita a Sade en el sentido de que si uno quiere saber sobre la muerte, uno debe mirar en lo erótico, o en la excitación sexual. El significado del erotismo, argumenta Bataille, radica en que ofrece la oportunidad de la transgresión contra el tabú más fundamental. Este es el tabú que separa la vida de la muerte. 'O', podría llamarse la ley de la discontinuidad, que limita a cada individuo en su

\footnotetext{
${ }^{18}$ Georges Bataille, Death and Sensuality (New York: Walker and Company, 1962).
} 
existencia separada, aislada, de la cual sólo puede liberarse por la muerte. La muerte es continuidad. Es en la muerte, no en la vida, que cada individuo se une con el resto, hundido en el mar indiferenciado. Lo que Bataille llama muerte, o continuidad, también puede ser visto como la unión, fusión o fundirse con la madre. Esta fusión o pérdida de fronteras se experimenta como muerte psíquica una vez que nos hemos separado -el regreso proverbial al útero. Se teme la pérdida de diferenciación como amenaza de muerte, sobre todo en ausencia de una verdadera diferenciación, que incorpore un sentido de unidad. Este miedo puede explicar por qué el individuo protege frenéticamente la propia frontera, incluso a costa de violar la de otro.

El cuerpo representa la discontinuidad, la individualidad y la vida. Consecuentemente, la violación del cuerpo, la violación erótica, rompe el tabú. Romper desde la discontinuidad hacia la continuidad, en términos de Bataille, constituye y requiere una violación. En el acto de la transgresión, el tabú es al mismo tiempo confirmado y violado. Violación expresa la pasión fundamental; la razón, preservando la discontinuidad y las fronteras propias, es la ley que lo mantiene bajo control. La frontera simultáneamente sostenida y rota une estos elementos en el único acto de violación ritual. De esta manera, la violencia y la razón se convierten en partes necesarias de un acto de dominio de la muerte. Mientras que se teme a la violencia como tal porque representa la pérdida de control, la violencia ritual o racional sostiene el control al romperlo. La pérdida de control es defendida mediante la pérdida o liberación controlada.

Bataille descubre la dialéctica hegeliana en el erotismo estableciendo la división entre el que mantiene el límite, y el que lo rompe. (O tal vez deberíamos decir, la que permite que su frontera sea violada, y el que lo hace). La relación contiene un actor y alguien sobre el que se actúa, un negador y un reconocedor. En absoluto para nuestra sorpresa, Bataille explica que en la forma ritualizada de la transgresión conocida como sacrificio, el varón es el actor y la mujer es la víctima. Sin embargo, argumenta Bataille, la mujer cumple la función de romper su discontinuidad, de arriesgarse a muerte, por los dos. Y, agregaría yo, 
el varón sostiene los límites de la razón para ella manteniendo su violencia dentro de los límites rituales.

El hecho de que la mujer permita que se rompa su límite y el varón lo rompa está en consonancia con las posiciones que tradicionalmente cada género al diferenciarse de la madre. La niña tiende a experimentar su continuidad y la fusión con la madre, y el niño tiende a afirmar sus límites. La posición masculina es hacer de la mujer un objeto, tanto mediante su violencia hacia ella como por su autocontrol racional. La posición femenina consiste en sentirse un objeto pasivo y aceptar su falta de control. La noción de Bataille respecto a que cada partener representa un polo en una unidad dividida, una parte de un todo interdependiente, sugiere que los roles pueden ser invertidos. Ambos parteners conocen y requieren su mitad opuesta.

Debido a que la transgresión que describe Bataille mantiene la tensión entre el control y la falta de control, afirma la frontera entre la vida y la muerte. La dominación erótica se construye para evitar la pérdida de la tensión esencial. Sin embargo, esto sólo puede funcionar si la relación amo-esclavo se promulga como fantasía, o en todo caso es restringida. De lo contrario, el resultado es la inevitable negación de un sujeto por otro. El problema de la lucha a muerte por el prestigio es que "el esclavo, al aceptar la derrota (...) ha perdido la cualidad sin la cual no puede reconocer al conquistador para satisfacerlo". El esclavo es incapaz de dar al amo la satisfacción sin la cual el amo ya no puede apoyarse"19. Para Bataille, la idea de Hegel de que cada uno debe estar dispuesto a arriesgarse a muerte para imponerse como absoluto sobre el otro revela la imposibilidad de la soberanía sin igualdad.

\section{La historia de ' $O$ '}

La pérdida total de tensión, o de diferenciación, es la muerte del yo. Quizás la forma más importante en la que los seres humanos experimentan la pérdida de la diferenciación es a través del sexo -muerte en otros términos. Las imágenes y

${ }^{19}$ Georges Bataille, "Hemingway in the Light of Hegel", Semiotexte 2, no. 2 (1976): 1. 
la promulgación de la dominación erótica han surgido recientemente de tal modo que hacen referencia explícita a esta conexión entre sexo y muerte. El cartel de una película reciente muestra a una mujer cuya garganta expuesta está rodeada por una delgada cinta roja y lleva el subtítulo: "La delgada línea entre el amor y la muerte es la línea de sangre". No puede sorprender, pues, que exista un paralelo tan fuerte entre la exploración de Hegel de la dialéctica de control en la relación amo-esclavo y la descripción de la subyugación erótica en The Story of O. Buscando una manera de explorar algunos de estos problemas de falsa diferenciación y racionalidad masculina, me sorprendió el hecho de que el masoquismo, o la sumisión voluntaria, requieren siempre de otro que permanezca en control. Este tipo de violencia racional, o más precisamente la violación, parece revelar un patrón a partir del cual se establece el yo mediante el control del otro, y la pérdida de la personalidad al ser controlado. La repetición de la lucha del niño para diferenciarse en la relación erótica adulta ofrece pistas sobre los componentes psicológicos de la dominación basada en el género. Interpretando la historia de ' $O$ ' a la luz de Hegel, intento mostrar cómo el fracaso de la diferenciación culmina en la dominación erótica.

La historia de ' $O$ ' es un intento excesivamente consciente de representar los temas de la dominación erótica - la tensión entre la separación y el reconocimiento, la racionalidad y la violencia, la trascendencia y la negación del yo, el falo activo y el orificio pasivo. Quizás la mayor objeción a este trabajo es su énfasis en la sumisión voluntaria de 'O'. Pero es sólo en virtud de la voluntad de ' $O$ ' que la alegoría de la lucha por el reconocimiento puede desplegarse. 'O' debe querer el deseo de su amante porque al hacerlo reconoce su deseo. Desea su voluntad, su deseo. Así, 'O' está constantemente reconociendo a su amante, y él la está negando constantemente. Esta polarización establece el escenario para el final, incluso cuando la relación está comenzando.

La historia se cuenta principalmente desde el punto de vista de 'O', la mujer. La novela deja claro que detrás de la humillación física y el abuso que 'O' sufre 
existe una búsqueda de una satisfacción espiritual o psicológica en última instancia inalcanzable. De Beauvoir señaló que el verdadero masoquismo consiste en querer el sufrimiento del dolor no por sí mismo, sino como prueba de la servidumbre. Es decir, el masoquismo es esencialmente un deseo de subordinación, más que la sumisión por la fuerza o la experiencia del dolor como tales. También afirma que el masoquista desea ser una cosa sujeta a la voluntad del otro para verse como un objeto para el otro ${ }^{20}$. Verdaderamente, sólo el yo que no ha renunciado a la pretensión de omnipotencia quiere someterse a la omnipotencia del otro, obteniendo así satisfacción vicaria. De Beauvoir distingue también este impulso sumiso del impulso de trascender el yo al entregarse a otra persona.

Esta distinción es crucial mientras veamos la relación entre los dos valores. El impulso sumiso está en relación con la trascendencia real como parte del todo. El masoquista se entrega a sí mismo mientras que el otro permanece en el control, por lo que no puede lograr la trascendencia de la que todo sí mismo es capaz. Pero esto constituye, nuevamente, un caso de una unidad que se ha dividido. Porque ella existe sólo en relación con otra que actúa, la niega, es reconocida incluso cuando ella es sólo el objeto de sus actos. De ahí que su renuncia al yo represente o signifique la unidad contradictoria que no alcanza. Por desgracia, por lo general, sólo en el conocimiento de las partes, en la experiencia de la polaridad, los parteners alcanzan la plenitud potencial que los une.

Al principio de La historia de 'O', nuestra heroína, cuyo nombre es evidentemente dado por la designación de la letra de la palabra Open u opening (Ouvert) o del orificio propio, es llevada al castillo de Roissy, organizado por varones para la violación ritual y subyugación de mujeres. No sabemos nada más sobre los varones, o su amante, René, y aprendemos poco más a lo largo

\footnotetext{
${ }^{20}$ Véase de Beauvoir, The Second Sex, pp. 444-46. En su exposición sobre la mujer enamorada, Beauvoir describe el entusiasmo religioso de "abolir los propios límites que la separan de su amante" -un entusiasmo que inspira a la mujer enamorada del hombre y a la mujer enamorada de Dios-, pero distingue esta "unión extática" del masoquismo, aunque puede degenerarse en autodestrucción y la destrucción para la mujer.
} 
del libro. La primera noche que ella está allí, los varones entregan este discurso a 'O':

Aquí estarás al servicio de tus amos ... dejarás de hacer lo que estés haciendo para cumplir con tu primera obligación, que es la de entregarte. Tus manos no te pertenecen, ni tus senos, ni mucho menos ninguno de los orificios de tu cuerpo que no nosotros podeos escudriñar y en los que podemos penetrar ... has perdido el derecho a rehusarte ... a nosotros nunca debes mirarnos a la cara. Si el traje que usamos ... deja el sexo al descubierto no es por comodidad ... sino por insolencia, para que tus ojos se fijen en él y no en otra parte, para que aprendas que éste es tu amo ... conviene que te acostumbres al látigo -ya que mientras estés aquí se te aplicará a diario- ello es menos para nuestro placer que para tu instrucción ... azotes y cadena ... sujetas a la anilla del collar ... no se trata de hacerte sentir dolor, gritar ni derramar lágrimas, sino, a través de este dolor, recordarte que estás sometida a algo que está fuera de tí ... ${ }^{21}$

En este breve texto es posible hallar muchas cosas. Primero, 'O' pierde toda subjetividad, toda posibilidad de usar su cuerpo para la acción; ella debe ser meramente una cosa. En segundo lugar, ella debe ser violada continuamente, incluso cuando no está siendo utilizada realmente -la principal transgresión de su propio límite se produce a través de tener que estar disponible y abierta siempre. Tercero, lo que me parece muy importante, es que sus amos son reconocidos por ella en una forma particularmente indirecta. El pene representa o simboliza su deseo ${ }^{22}$. Al interponerse entre ellos, pueden mantener un yo, una subjetividad independiente de su reconocimiento. Y esta subjetividad se expresa a través del poder de los amos sobre ella de una manera más general, en su habilidad total para organizar, calcular y controlar el efecto que están teniendo sobre ella. De hecho, lo que hacen es "más por su instrucción que por su placer" -incluso al usarla no la necesitan. Más bien, sus

\footnotetext{
${ }^{21}$ Rage, The Story of O, pp. 15-17.

${ }^{22}$ Gayle Rubin ofrece una teoría más general del falo como símbolo y mediación del deseo masculino, en "The Traffic in Women: Notes on the 'Political Economy' of sex," en Toward an Anthropology of Women, ed. Rayna R. Reiter (New York: Monthly Review Press, 1975), pp. 157210.
} 
actos expresan un control racional, una violación racional a través de la cual objetivan sus intenciones racionales. Cada acto tiene una meta o propósito que afirma su dominio. Disfrutan no tanto de su placer, como del hecho de que pueden tomarlo. Disfrutan no tanto de su dolor, como del hecho de que producen un efecto visible sobre ella: dejan sus marcas.

¿Por qué deben encontrar placer más en su mando que en su servicio, y por qué debe estar mediado a través del cálculo, o simbolizado por el pene? Debido a que siempre deben mantener su subjetividad separada, nunca deben ser dependientes. De otro modo, sufrirían la suerte del amo de Hegel, quien al depender de su esclavo poco a poco pierde subjetividad. Otro peligro para el amo es que el sujeto siempre se convierte en el objeto que consume. ("Tú eres lo que comes"). Por lo tanto, deben tener cuidado de no consumirla completamente como un objeto sin voluntad, sino más bien mandar y consumir su voluntad. Siempre le preguntan, "O, ¿estás de acuerdo?" Por supuesto, al consumir la voluntad de 'O', la están negando y se reconocen en la voluntad propia; están inevitablemente depreciando su voluntad y convirtiéndola en un objeto. Cuando su objetivación es completa, cuando ella no tiene más voluntad para dar, o se rinde, no pueden continuar ocupados con ella sin estar llenos de ella como algo natural. Deben realizar su violación racional y ritual tanto para mantener sus límites como para hacer de su voluntad el objeto de sus voluntades.

Finalmente, lo que es significativo sobre la simbolización del amo masculino a través del pene es el énfasis en la diferencia entre ellos y ella ${ }^{23}$. Significa el pronunciamiento masculino de la diferencia sobre la mismidad. Cada acto que el amo toma contra su esclava, 'O', es aquel que establece su separación, su diferencia con ella, su no-identidad con ella -mediante su poder de negarla. En la tensión entre el reconocimiento de la conexión como humanos y la negación de la Otredad, el varón representa el extremo unilateral. Lo que está haciendo es ponerse permanentemente fuera de ella diciendo continuamente "Yo no soy

\footnotetext{
${ }^{23}$ Chodorow, "Difference, Relation and Gender".
} 
tú". Él la está utilizando para establecer su realidad objetiva imponiéndola sobre ella. La función racional, el cálculo, la objetividad y el control están vinculados a esta diferenciación unilateral, este "yo no soy tú", de la manera en que Bataille la ligaba inherentemente a la discontinuidad. La violencia, al servicio de la razón, tiene la misma intención de afirmar la propia frontera de control. El pene simboliza el hecho de que, por muy interdependientes que sean amo y esclavo, siempre mantendrá la frontera: la rigidez, el antagonismo y la polarización de sus respectivas partes.

A través del movimiento de la dialéctica del control, la narrativa revela las consecuencias de tal separación negando al otro. La historia está realmente impulsada por la naturaleza problemática del control como medio de diferenciación. Porque el esclavo que está completamente dominado pierde la cualidad de ser capaz de reconocer, porque lo que ya es poseído no existe fuera, la lucha debe prolongarse. 'O' debe ser esclavizada pieza por pieza, por así decirlo. Se deben encontrar nuevos niveles de resistencia, para que puedan ser vencidos nuevamente. Ella debe consentir profunda humillación, dolor, y esclavitud, y debe someter su voluntad cada vez. La narración se mueve a través de estos niveles cada vez más profundos de sumisión, trazando el impacto de cada nueva negación de su voluntad, la derrota de su resistencia, hasta su muerte.

Hasta ahora hemos notado que 'O', al someterse, reconoce el deseo de su amante, mientras él sólo la niega. Pero esto no es del todo cierto. Hay un sentido en el cual, desde el principio, su esclavitud la hace incapaz de reconocerlo. Y él tiene tal control sobre ella que no arriesga nada, ciertamente no se arriesga a (su propia) muerte. Ella es más la objetivación del deseo de él que un sujeto humano que lo reconoce, y él reconoce en ella el objeto de su deseo. Así, aunque 'O' quiere ser reconocida por el-sujeto-René, él la usa como un objeto en su lucha por el reconocimiento.

El problema narrativo, la culminación de la dialéctica, ocurre en el momento en que ' $\mathrm{O}$ ' se ha sometido y ya no puede reconocer a René, y ha agotado las posibilidades de violar sus límites. El problema se resuelve con la introducción 
de Sir Stephen, el hermanastro mayor a quien René la entrega. 'O' entonces se da cuenta de que es un objeto en el esfuerzo de René por ganar prestigio de Sir Stephen, quien es más importante para René de lo que ella puede llegar a ser. Sir Stephen no "ama" ni reconoce a 'O' (al menos, no al principio), por lo que la sumisión de ' $O$ ' a él es una sumisión a un poder puro que no requiere reconocimiento de ella a cambio. Ella es, él le dice, humillada por alguien que no la ama en presencia de quien sí lo hace. Sir Stephen es completamente racional, calculador y autocontrolado en su deseo.

Igualmente sugerente es el hecho de que René ve a Sir Stephen como a un padre. Aquí hay más que un indicio de la relación edípica. Sir Stephen es la autoridad no sólo para 'O', sino también para René. Él es la persona en cuyos ojos René quiere ser reconocido. La entrada de Sir Stephen sugiere una reinterpretación de la historia hasta ese punto. Ahora vemos que René es débil y siempre ha estado bajo la influencia de un hombre mayor más poderoso. Este desarrollo de la historia nos recuerda que la dominación masculina está arraigada en una lucha por el reconocimiento entre hombres en los que las mujeres son meros objetos o fichas: el premio. En términos de desarrollo psicológico, la relación de dominación no sólo se basa en el drama pre-edípico de la separación madre-hijo, sino que también se perpetúa en la tríada edípica. En el conflicto edípico, el padre impone la separación del niño de su madre, exigiendo no sólo que la abandone como un objeto de amor, sino también como un sujeto con el cual identificarse. La agresión o interferencia del padre, con la que el niño se identifica o a quien internaliza, se vuelve a representar en el repudio y la objetivación de la madre. En otras palabras, la postura del niño de repudiar a la madre y afirmar sus propios límites está inspirada en el padre poderoso y diferente. Buscando el reconocimiento de este padre, el niño está aspirando a no ser objeto de cuidados, sino a ganar prestigio. Lo gana repudiando a la madre tan visible, tan violentamente como sea posible.

El hecho de que René está dispuesto a renunciar a ella por Sir Stephen hunde a 'O' en la desesperación, ya que sólo puede existir si René la reconoce. Sin él, sin su amor, que significa que él depende de ella, la vida es absolutamente 
vacía. Ella piensa, parafraseando un texto protestante que ella vio cuando era niña: "Es algo temible ser expulsada de las manos del Dios viviente". Vemos que su experiencia tiene un carácter religioso. Esto se elabora no sólo mediante la violación ritual de su cuerpo como barrera hacia la continuidad, el infinito; ella misma también experimenta a su amante como un dios a quien adora y del que no puede soportar separarse. Mientras que Dios representa la unidad final, la capacidad de estar solo, 'O' representa la dependencia abyecta, la incapacidad de tolerar la separación y la soledad.

El autor nos dice que el abandono por Dios es experimentado como castigo e indicador de culpabilidad. Normalmente, una se pregunta qué se ha hecho para merecer esto y busca la causa en sí misma. Abandonada por René, castigada por Sir Stephen, 'O' encuentra la culpa en su lascivia, su deseo. 'O' está realmente dispuesta a arriesgarse a morir para seguir siendo el objeto del deseo de su amante, para ser reconocida. Su gran anhelo es ser aprehendida, y en este aspecto es como cualquier amante, pues el secreto del amor es ser aprehendida como una misma. Pero el deseo de 'O' por ser aprehendida es más bien como el pecador que quiere ser conocido por Dios. Sir Stephen la estremece y se deleita en su abatimiento, en parte, porque él sabe desde el momento en que la conoce que ella es mala, lasciva, "fácil".

La culpa más profunda de ' $\mathrm{O}$ ' no se debe, sin embargo, a su deseo de ser reconocida por René o Sir Stephen, sino por la posibilidad de que se sienta tentada a actuar según su deseo. Actuar es negar a otro, ser un sujeto. 'O' se niega a masturbarse delante de Sir Stephen porque su más profunda vergüenza está conectada a este flagrante acto de autonomía, que dice "Puedo satisfacerme a mí misma". También descubrimos que 'O' siempre ha deseado poseer a mujeres, para que se entreguen a ella, pero ella nunca se entregó antes de encontrarse con René. Así que ' $O$ ' está siendo castigada por dos aspectos de su subjetividad, el deseo de ser aprehendida, y el deseo de negar, de actuar, de separarse. En particular, sospecho que este último, tal vez porque es la prerrogativa del varón, sea su verdadero pecado: la afirmación de la autonomía, del yo como agente. 
'O' se anima a azotar, así como hacer el amor con otras mujeres en el curso de su esclavitud. Pero su desempeño independiente del papel activo (antes de su esclavitud) es pecaminoso. En parte, implica el autor, su negativa a entregarse era verdaderamente de mala fe, y el castigo y la esclavitud de 'O' es el destino de alguien que no podia amar verdaderamente. Ella no es capaz de entregarse como una persona entera y separada. Tanto su incapacidad para tolerar el abandono y la separación, así como su rechazo culpable de toda autoafirmación, inevitablemente llevan a 'O' a su muerte. Es difícil no ver el continuo consentimiento y afirmación de ' $\mathrm{O}$ ' en su propia esclavitud como huida de la soledad y separación del agente libre. Sin embargo, no me limito a decir que 'O' está huyendo de la libertad. Aunque esto puede ser cierto, también parece estar en busca de otro tipo de libertad. Es la libertad de la devoción a su dios. Aunque la verdadera trascendencia y la libertad están constituidas por la libre entrega del yo en una relación recíproca, ' $\mathrm{O}$ ' encuentra una especie de trascendencia suplente, o pérdida de sí misma, en su esclavitud. Esta pérdida de sí misma es lo opuesto de perder al otro, de estar sola. Podríamos decir que su búsqueda de lo ilimitado, de la verdadera unión, de la experiencia religiosa, se convierte en sumisión y esclavitud porque no está separada, no puede soportar la soledad. Consiente la propia esclavitud para trascender su soledad (discontinuidad) sin sufrir separación.

¿Cómo se conecta el dolor con la trascendencia de sí misma? "A ella le gustaba la idea de la tortura, pero cuando ella estaba siendo torturada ella misma habría traicionado al mundo entero para escapar de él, y sin embargo, cuando terminó, se alegró de haberlo pasado" 24 . Lo más obvio es que el dolor significa la sumisión a la voluntad del otro. Pero ¿por qué el dolor tiene este significado? Lo que diferencia el placer del dolor, en términos de Freud, es que el dolor es el punto en el que los estímulos se vuelven demasiado intensos para que el cuerpo o el ego puedan soportarlo. El dolor es la violenta ruptura de la

\footnotetext{
${ }^{24}$ Rage, The Story of O, p. 152.
} 
autoorganización ${ }^{25}$. Es esta pérdida de autoorganización que 'O' acoge bajo ciertas condiciones dadas ${ }^{26}$. A la inversa, el placer siempre implica cierta cantidad de control o dominio de los estímulos. De ahí que el amo pueda conocer el placer, el dominio de la satisfacción y el esclavo quien deba experimentar el dolor. En su violación y pérdida de sí misma a través del dolor, en las marcas de esta violación, el cuerpo de 'O' está "moviéndose" hacia sus amos (como otra mujer cautiva se está moviendo hacia 'O'). Esta "emoción", sin embargo, siempre se verifica y finalmente disminuye a medida que se convierte en un objeto más deshumanizado, ya que es sólo el espectáculo de ella lo que los mueve. 'O' finalmente alcanza la independencia por estar dispuesta a ir hasta el final, a arriesgar su vida con el fin de obtener el reconocimiento. Su experiencia de la muerte psíquica a través del dolor de la auto-ruptura es su forma de trascendencia.

Aparentemente contradictorio, pero quizás complementario, es el uso del dolor para simbolizar el nacimiento, la individualidad y la separación. El dolor psíquico de la separación es capturado en el dolor físico infligido a los violados. La cercanía del nacimiento y la muerte, la pérdida del yo y la autoconciencia en las imágenes del dolor nos recuerdan que en realidad el sentido más intenso del yo implica sentimientos contradictorios. La verdadera diferenciación, he argumentado, es un todo en tensión entre la negación y el reconocimiento, afirmando singularidad y conexión, continuidad y discontinuidad a la vez. La esperanza de ' $O$ ' - de que en la sumisión completa y la aceptación del dolor encontrará su sí mismo elusivo- puede ser visto como un intento de experimentarse a sí misma al arriesgarse a la muerte.

\footnotetext{
${ }^{25}$ Véase Leo Bersani, Baudelaire and Freud (Berkeley: University of California Press, 1977), p. 77. Bersani muestra cómo la poesía de Baudelaire se mueve cada vez más desde la fantasía del deseo a través de la violencia hacia la muerte (asesinato), ilustrando perfectamente el agotamiento de la sensación del sádico.

${ }^{26}$ Como decía Beauvoir, la verdadera violación que la joven imagina sería terrible si de hecho sucediera. Esto se debe a que en la imaginación la violencia sigue bajo control, mientras que en la realidad está fuera de control.
} 
Si aceptamos la idea de que 'O' consiente el dolor y la esclavitud debido a una búsqueda de la trascendencia, todavía queremos saber por qué ella elige esta forma, en lugar de la posibilidad de la entrega mutua, recíproca de sí misma. Queremos saber esto de la misma manera que queremos saber por qué, para Hegel, la lucha por el reconocimiento termina en la relación de poder en vez de en una auto-soberanía recíproca e igualitaria. Bataille sugiere una respuesta con su idea de la transgresión, o violación, que rompe y sostiene la ley. Permite que un partener permanezca racional y en control, mientras que el otro pierde sus límites. De hecho, es la actitud racional, calculadora e incluso instrumentalizadora del amo la que excita la sumisión, la imagen de su exquisito control constituye su emocionante machismo. El placer, para ambos miembros, está en su dominio. Si ambos acordaran renunciar a sí mismos, abandonar el control, la desorganización del yo sería total. El yo masoquista no podría identificarse con la parte que permanecía en control. ' $O$ ' no podría experimentar su pérdida de control como una pérdida controlada. Ella no podría ceder "con seguridad" a su impulso de perder el control. Cuando el límite se disuelve libremente, en lugar de romperse debido a que se mantiene su frontera, una queda desprotegida ante lo desconocido, infinito y aterrador. Puede ser, entonces, que la motivación primaria para mantener la desigualdad en la relación erótica y, en última instancia, para establecer la constelación amo-esclavo, sea el temor a la pérdida del ego: lo ilimitado. Y tal vez la ilimitada infinitud de la plenitud es tan temible como la infinitud de la vacuidad. La relación amo-esclavo está diseñada para resolver un problema que de hecho perpetúa. La división rígida en amo y esclavo, sádica y masoquista, agota en última instancia su potencial para la trascendencia. Ninguno de los dos puede ser reconocido y negarse activamente. Al igual que la pareja en el reloj de cucú, uno siempre debe estar fuera cuando el otro está dentro; nunca se encuentran. Si la tensión se disuelve, la muerte o el abandono es el final inevitable de la historia, y La Historia de ' $O$ ' queda deliberadamente abierta a ambas conclusiones. Esta ambigüedad es apropiada porque el destino masoquista o intolerable es el abandono, mientras que para el sádico es la muerte/asesinato 
del otro a quien él destruye. El dominio que él logra sobre el otro es insatisfactorio, porque cuando el otro es drenado de la resistencia ella solamente puede ser vencida por la muerte. Metafóricamente, la relación sadomasoquista tiende hacia la inercia, el entumecimiento, el agotamiento de la sensación, la inmovilidad total. Está atrapada en la dialéctica de la objetivación, donde el sujeto se vuelve cada vez más como el otro objetivado que consume. De una forma u otra, controlar al otro es el fin inevitable de la existencia. La relación de dominación se basa en la fantasía de la omnipotencia y la negación de la realidad separada del otro. En consecuencia, está impregnada de la frustración de ese sentimiento de irrealidad: nadie está realmente allí para reconocerme.

La afirmación de la omnipotencia y la negación del otro es más bien una frágil defensa contra la continuidad, lo ilimitado. En cualquier momento puede irrumpir en el amo la percepción de que está realmente solo porque la persona con quien está no es ninguna persona en absoluto. Por su parte, el esclavo teme que lo abandone a la soledad porque se cansará de estar con alguien que no es una persona. Sólo cuando la esclava se afirma como una persona en su propio derecho y afirma su libertad, el amo se frente al hecho de que él también depende de ella para el reconocimiento -ya sea directa o indirectamente porque el amo la posee 27 . Esta dinámica de la dependencia es bastante familiar en las relaciones eróticas adultas. A menudo, aunque no siempre, el varón asume el papel de afirmar la diferencia, la mujer la dependencia. La no-reciprocidad es un residuo constante en cualquier diada. Uno da, el otro se niega; uno persigue, el otro pierde interés; uno se hace el dificil, el otro persigue; uno critica, el otro se siente juzgado. La aspiración a la reciprocidad es constantemente socavada por el profundo temor de perder las fronteras y la omnipotencia mental. El temor a la intrusión, el deseo de ser autosuficientes, de ser impasibles, son maneras familiares de evitar la confrontación cruda con la realidad de la existencia del otro, aparte de mí, al que aún necesito.

${ }^{27}$ Los pronombres de género se usan aquí para mayor claridad, pero de ninguna manera expresan un conjunto inevitable de roles. 


\section{Algunas pistas psicoanaliticas sobre los origenes del sadomasoquismo}

Quedan pendientes las respuestas a dos preguntas. Una es si la afirmación de la omnipotencia mental es, como Hegel lo representa, un estado original o natural ${ }^{28}$, o si se trata de una postura defensiva que las personas, en su deseo de reconocimiento, aborrecen mantener tanto como abandonar. Y segundo, ¿por qué la violencia desempeña un papel tan importante en la dominación erótica? Para responder a estas preguntas debemos volver a la cuestión de la diferenciación e insistir más allá de nuestra explicación anterior respecto a que el niño repudia a la madre para lograr autonomía. Tal vez la frustración de la relación sadomasoquista es una señal. ¿Podría significar una repetición de la experiencia temprana? La naturaleza de la agresión o la violencia y el origen del sadismo son temas muy amplios; y no puedo hacerles justicia aquí. Pero ciertas formulaciones psicoanalíticas arrojan luz sobre los fenómenos que estoy tratando de identificar como la dialéctica del control sobre la inevitable y frustrante pérdida de la realidad del partener.

Freud describió el desarrollo del sadismo como un proceso complicado. Primero, pensó que la relación del infante con el mundo se caracteriza por un sadismo primario ${ }^{29}$. Con esto se refería a un deseo de dominio en el cual al niño le es bastante indiferente la otra persona. No sabe que sus ataques voraces, a veces con sus dientes, sobre el pecho es perjudicial para la madre. Además, su (fantaseada) destrucción del objeto -consumirlo, devorarlo, incorporarlo de alguna forma- no se experimenta con vistas a las consecuencias que afectan al

\footnotetext{
${ }^{28}$ Lacan, por ejemplo, toma de esta suposición su análisis del ego, y con él la inevitabilidad de una diferenciación falsa; véase Jacques Lacan, "The Mirror Stage as Formative in the Function of the I", trads J. Roussel, New Left Review no. 51 (1968): 71-77. Las consecuencias de este análisis se hacen evidentes cuando son adoptadas por las feministas, como en el trabajo de Juliet Mitchell, Psychoanalysis and Feminism (New York: Pantheon, 1974), donde la Ley del Padre es vista como un requisito previo inevitable para el desarrollo y la diferenciación.

${ }^{29}$ Freud, "Instincts and Their Vicissitudes", pp. 91-92.
} 
otro, y mucho menos de herirla. El niño todavía no es consciente de que perderá al otro al incorporarlo. Esta indiferencia inicial hacia el destino del otro también permite la posibilidad de que el otro sobreviva a cualquier ataque. Tal vez el bebé incluso desea y espera la supervivencia del otro como en el caso "comer su pastel y también tenerlo". El sadismo real, el deseo de infligir dolor, sólo ocurre después de que el niño haya experimentado el masoquismo, sólo después de haber interiorizado, convertido en sí mismo, el sadismo original ${ }^{30}$. A través de esta internalización viene la habilidad de desempeñar ambos roles en la fantasía, experimentar vicariamente la parte del otro, lo cual da sentido al acto de violación.

Ahora bien, la cuestión decisiva es si esta descripción de un impulso primario inocente de dominio vira realmente hacia la idea de que los niños "naturalmente" quieren mantener la omnipotencia y se imponen al mundo. En última instancia, lo que decidimos acerca de esto puede ser más una cuestión de fe que de evidencia, como probablemente fue cierto para Freud. Pero todavía podemos encontrar otra manera de entender la violencia mediante el razonamiento de la observación clínica. Esto es exactamente lo que hizo el psicoanalista D. W. Winnicott. Winnicott sostuvo que el acto destructivo, en su inocencia original, podría ser entendido como un intento de renunciar a, no mantener, la omnipotencia ${ }^{31}$. Originalmente, la agresión no es una reacción de enojo ante la realidad, sino un impulso diferenciador primario que ayuda a establecer la realidad. Como se dijo anteriormente, el reconocimiento de los actos del sujeto otorga el sentido significativo del sí mismo y de las relaciones con los demás. Pero es importante que el otro sea afectado, no completamente negado o destruido. Winnicott propone que el bebé siempre está "destruyendo" al otro en la fantasía, que lo está atacando (negándolo), pero se complace si encuentra que el otro continúa sobreviviendo. El bebé espera que haya hecho lo

\footnotetext{
${ }^{30}$ Ibid.

${ }^{31}$ D. W. Winnicott, "The Use of an Object and Relation Through Identifications," in Playing and Reality (Middlesex: Penguin, 1974), pp. 101-11.
} 
que fantasea, pero descubre con alivio la ineficacia de la fantasía. E1 descubrimiento le permite experimentar al otro como portando una verdadera existencia independiente, tomar conciencia de que el otro es verdaderamente exterior y no se encuentra totalmente controlado por el aparato mental del sí mismo ${ }^{32}$. Este ataque originalmente inocente, o dominio, no es tanto un intento para imponer el sí mismo al otro como puede parecer. Más bien, es un intento de colocar al otro fuera de la esfera del control mental de la omnipotencia. Su objetivo, o por lo menos su efecto, es chocar con la resistencia del otro y establecer firmemente su presencia sólida e independiente. La supervivencia del otro es la muerte de la omnipotencia mental, pero esta "muerte" es lo que realmente da al otro "vida".

De hecho, Winnicott confirma el modo en que Freud comprende cómo inicialmente la fantasía agresiva no es un impulso para dominar o ser sádico. Inicialmente, la violencia es una expresión del impulso de negar, de afectar a otros, de ser reconocido. Pero sugiere que hay una interacción entre el bebé y la madre que da como resultado lo que Freud describe como los siguientes pasos: primero, la interiorización del sadismo como masoquismo, infligiendo luego este daño a otra persona. El fracaso de la madre en "sobrevivir" al ataque, es decir, absorberlo sin reaccionar, hace que el bebé vuelva su agresión hacia adentro y desarrolle lo que conocemos como ira33. La ira es una reacción al retiro del otro

\footnotetext{
32 Ibid., p. 106. Winnicott también señala que lo que realmente se encuentra desarrollando es una idea de cómo el sujeto se relaciona con la realidad, completamente diferente de la del pensamiento psicoanalítico clásico. "A partir de ahora, en esta etapa alcanzada, los mecanismos proyectivos ayudan al acto de darse cuenta de lo que está allí, pero no son la razón por la que el objeto está ahí (...) Esto es una alternativa a la teoría que tiende a una concepción de la realidad externa sólo en términos de los mecanismos proyectivos del individuo". Añadiria que en la teoría de Freud, no hay descubrimiento de la realidad o del otro como un sujeto emocional; sólo hay una conciencia cognitiva o funcional de los demás. Ese sentido elevado de la vivacidad que acompaña al reconocimiento de otro sujeto entra en la teoría de Freud de manera periférica, en todo caso, sólo en sus comentarios sobre el amor. No percibe el problema de la realidad intersubjetiva en sí misma.

${ }^{33}$ Ibid., p. 110: "No hay ira en la destrucción del objeto al que me estoy refiriendo, aunque se podría decir que hay alegria por la supervivencia del objeto". Extiendo el argumento de Winnicott diciendo que si el objeto no puede sobrevivir, entonces la ira se convierte en una característica de la destrucción, y la destructividad se vuelve real.
} 
o a las represalias del otro. La autoafirmación original se convierte entonces de dominio inocente a dominio sobre y contra el otro. El relato de Winnicott implica que la violencia comienza simplemente como el impulso diferenciador, como una manera de colocar al otro fuera de los límites del yo. Él (como los psicoanalistas en general) no considera el tipo de condiciones que permitirian a una madre, o, más generalmente, a una primera otra sobrevivir como un sujeto independiente para el niño. Pero el análisis de Winnicott proporciona una pista de la naturaleza repetitiva y agotadora del sadomasoquismo. Cuando el otro no establece un límite, cuando no sobrevive, el niño debe seguir destruyendo y atacando, seguir buscando un límite para su ira reactiva. Ahora la naturaleza del ataque cambia, se vuelve literalmente violenta, dañina en la intención. La falta de supervivencia del otro crea un vacío para el sujeto. Incluso sin represalias directas, si el otro ingresa y se retira bajo mi acto, mi acto cae del borde de ese vacío, y una siente que será la siguiente ${ }^{34}$. En este vacío empieza el temor de lo ilimitado.

Para el masoquista y el sádico, la búsqueda apunta al límite de la otra persona como una protección contra el vacío y la ira. El masoquista se expone a lo ilimitado en su sí mismo, mientras que el otro continúa sobreviviendo, para mantener límites, para controlar. Pero el masoquista también revive la represalia por su autoafirmación a manos del sádico. Sin embargo, ninguno de los dos es capaz de lograr la satisfacción de atacar al otro y de percibir la supervivencia del otro. No hay alivio al descubrir que la agresión de uno no es tan destructiva después de todo, por tener otra presencia que puede tolerar sus impulsos y verdaderamente evitar el vacío. En otras palabras, la relación de la dominación erótica es una repetición que revive una frustración anterior del impulso de la diferenciación. Expresa la violencia cuya dirección original era situar al otro fuera del yo. A falta de esto, la dominación erótica busca lo que la violencia no pudo lograr originalmente en forma alienada o simbólica. Pero al

\footnotetext{
${ }^{34}$ Creo que se podría decir mucho más respecto de la forma en que el propio sentimiento de ser tan ineficaz como para no poder dañar a alguien es responsable de un comportamiento destructivo y violento. Comienza con la impermeabilidad del otro.
} 
hacerlo, simplemente repite la frustración anterior de destruir en lugar de descubrir al otro, de someterse al control en lugar de ser reconocido.

Extendiendo la línea de pensamiento de Winnicott, sugeriría que el sujeto está tratando de expresar un impulso diferenciador básico. Esta búsqueda persiste como violencia hasta que triunfa. La repetida experiencia de la frustración no disminuye el impulso diferenciador en gran medida, ya que convierte y distorsiona su expresión al combinarlo con la ira. Primero, el acto de colocar al otro fuera se convierte en afirmación de control o posesión sobre él o ella, en una negación de la propia dependencia. En segundo lugar, el esfuerzo por controlar el impulso violento racionalmente sustituye a la satisfacción de la necesidad original.

El esfuerzo para controlar el impulso diferenciador, en lugar de actuar sobre él, es lo que hace al carácter racional de esta violencia. Debido a que el otro no proporciona una frontera, que tanto contiene y permite la unidad de diferenciación, uno tiene que proporcionar su propio límite. Uno tiene que desempeñar ambos roles por sí mismo -y, como jugando cualquier juego valiéndose por sí mismo, está solo. En la dominación erótica adulta, el sádico tiene que comprobar y controlar sus propios impulsos y no tiene la satisfacción de que el otro proporciona un límite. El masoquista obtiene esta satisfacción, pero no por su propio impulso diferenciador, sino sólo indirectamente por el sádico. La violencia racional repite o re escenifica el proceso original de diferenciación falsa. La contención de la violencia a través de la adhesión a una frontera racional sustituye al acto diferenciador de negar al otro y disfrutar de su supervivencia. En la diferenciación falsa, el otro puede ser formalmente reconocido como otro sujeto, pero de hecho es sentido como un objeto o un instrumento. En la violencia racional, el otro sólo sobrevive como un objeto, no como otro sujeto que pueda reconocernos y liberarnos. Estoy argumentando que, aunque toda violencia es un fracaso de la diferenciación -una incapacidad de reconocer el derecho del otro a existir para sí- la violencia racional es un caso especial. Emplea el deseo o voluntad del violado y exige el control racional del violador (en la violencia no racional, la víctima no juega ningún papel en 
absoluto). Los participantes infunden a la relación anhelo de reconocimiento y separación mientras se protegen de las experiencias reales de soledad o reciprocidad. La violencia racional, tal como se manifiesta en el sadomasoquismo, es un sustituto calculado de la autotrascendencia real y de la verdadera diferenciación. También es un sustituto para el dolor y la ira de ser incapaz de destruir con éxito y redescubrir el otro.

Al hablar de un sustituto -una expresión distorsionada o alienada- para el impulso de diferenciar, me refiero a lo que a menudo se describe como defensa ${ }^{35}$. La afirmación de que un proceso psíquico o interpersonal particular sirve de defensa es fácilmente incomprendida. Puede parecer que en cuanto a la denominación de una defensa, se cuestiona la importancia o tenacidad de la misma. Muy por el contrario. Tematizar a la violencia racional en términos de defensa es insistir en que por debajo de ella, por muy inaccesible que sea, existen otros anhelos que tanto expresa como niega. El aspecto esencialmente defensivo de la relación sado-masoquista radica en la división de dos impulsos que deben ser conservados en tensión entre sí. La función de los impulsos en el establecimiento de un sentido de la realidad y la independencia se ve afectada. En el proceso de diferenciación falsa, el énfasis unilateral en separar y trazar fronteras excluye y desvía contra la fusión y la identificación. En la relación sadomasoquista, la división permite a cada socio enfatizar y excluir los aspectos opuestos de la diferenciación -el aspecto destructivo o negador y el aspecto de descubrimiento y reconocimiento. La división entre la autonomía y el reconocimiento, la independencia y la dependencia mutua, está en la raíz de la dominación.

Significativamente, la tendencia de los hombres a enfatizar la independencia y la separación en la diferenciación corresponde al papel de destruir y negar en la dominación erótica. La postura masculina, ya sea asumida por todos los

\footnotetext{
${ }^{35}$ Una noción crucial para mi perspectiva teórica aquí, y que surge de la teoría de las relaciones objetales de W. R. Fairbairn, es que ciertos procesos que Freud vio como necesariamente constitutivos del yo son en realidad defensas. Véase su teoría de las relaciones objetales W. R. D. Fairbairn, Psychoanalytic Studies of the Personality (London: Routledge Kegan \& Paul, 1952).
} 
varones o no, prepara para el rol de amo. El varón está dispuesto a objetivar al otro, a instrumentalizar y calcular su relación con ella para negar su dependencia. La postura femenina dispone a la mujer para aceptar la objetivación y el control para huir de la separación, tanto como soledad y como autoafirmación. Él afirma la propia individualidad, mientras que ella renuncia a ella.

\section{La hegemonia cultural de la violencia racional masculina}

¿Cómo se relaciona esta postura psicológica diádica con las formas culturales y sociales más amplias de la dominación masculina? Quiero argumentar que la racionalidad y la individualidad tradicionalmente masculinas son culturalmente hegemónicas, mientras que lo ilimitado y la sumisión tradicionalmente femeninas son negadas y reprimidas. Sin embargo, moralmente condenadas por la sociedad, la dominación, e incluso la violencia, no evocan el mismo miedo y odio como el espectáculo de la víctima. Además, y fundamentalmente, la racionalidad masculina y la violencia están vinculadas dentro de instituciones que parecen ser asexuadas y sin género, pero que exhiben las mismas tendencias para controlar y objetivar al otro fuera de la existencia que encontramos en la forma erótica de la dominación. Es decir, la postura masculina en nuestra cultura está encarnada en formas extremadamente poderosas y peligrosas de destructividad y objetivación.

Así como el miedo popular existente ante la posibilidad de que el poder científico y tecnológico destruya nuestro planeta ha circulado en todas partes y en todos lados desde la bomba atómica, la idea de que al destruir la naturaleza el hombre se destruiría a sí mismo también ha circulado desde mucho antes. La preocupación por la tendencia de la mente científica a matar su objeto, ya sea literalmente o en la fantasía, es al menos tan antigua como el romanticismo. La crítica romántica de la racionalidad masculina nos es familiar en el Frankenstein de Mary Shelley, o en el Chillingsworth de Nathaniel Hawthorne, un demonio de la razón calculada que se venga contra los sentimientos y las pasiones que amenazan a la autoridad. La crítica sociológica 
contra la racionalidad encontró su mayor articulación en la obra de Max Weber a comienzos del siglo ${ }^{36}$. Weber argumentó que cierto tipo de cálculo racional, característicamente occidental, subyacía al capitalismo. Esta racionalidad reduce el proceso o la actividad a un mero medio, a su producto. Él llamó a esta razón instrumental. Debido a que impregna nuestra cultura, he sugerido el término cultura instrumental ${ }^{37}$. A medida que esta forma de racionalidad llega a dominar en nuestra cultura, las formas anteriores de autoridad religiosa y moral son reemplazadas. La interacción social se despersonaliza. El mundo se vuelve "desencantado", desprovisto de experiencia colectiva trascendente. El hecho de que las necesidades humanas no dictan la producción en el capitalismo, argumentó Weber, implica una voluntad de subordinar la necesidad a la ganancia. Para que el capitalismo se desarrolle, esta voluntad ya debe haber estado presente en la incorporación de la racionalidad y el cálculo de la cultura en las formas religiosas y juridicas que precedieron a la industrialización. Creo que el argumento de Weber debe extenderse para significar que la hegemonía masculina en la cultura se expresa por la generalización de la racionalidad. Esto conceptualizaría una forma en la que la dominación masculina precede y prepara el camino para el capitalismo.

La racionalización y la despersonalización en las esferas públicas de la vida prácticamente destierran el cuidado de la familia privada, el menguante mundo materno. El repudio del reconocimiento entre las personas y su desplazamiento por las formas objetivas impersonales de la relación social es el homólogo social del repudio masculino de la madre. El confinamiento doméstico de la crianza establece literalmente el escenario para la incapacidad de apreciar la subjetividad de la madre al privarla del reconocimiento social.

Aunque estas conexiones sólo pueden ser elaboradas de forma abstracta y esquemática en este ensayo, vale la pena explorar cómo el proceso de

\footnotetext{
${ }^{36}$ La definición más extensa de Weber sobre Zweckrationalitaet, es traducida de manera diversa como racionalidad instrumental o de objetivos, aparece en Economy and Society, ed. G. Roth and C. Wittich, trads. E. Fischoff y otros (New York: Bedminister Press, 1968).

${ }^{37}$ Véase mi discusión sobre cultura instrumental en "Authority and the Family Revisited".
} 
diferenciación se ve afectado por formas culturalmente encarnadas de racionalidad masculina. En primer lugar, sugeriría que la privatización de la nutrición indudablemente conduce a una posición más débil para la madre, y es su fragilidad -no su poder- lo que la hace incapaz de tolerar y alentar la diferenciación de su hijo ${ }^{38}$. Cuanto más depende la madre de su hijo así como de su tarea, su sentido, su forma de gratificación, menos desinteresada es, y más intensos son sus sentimientos en torno al proceso de diferenciación. Si ella es demasiado permisiva y tiene miedo de afirmar sus propias necesidades, esto hace que el niño se sienta perdido. Por otra parte, si se sitúa socialmente de tal modo que la maternidad de unos cuantos hijos constituye su principal tarea, es particularmente vulnerable a connotar todos los actos de su hijo como piedras de toque para su propia autoestima, como reflejo de su éxito y fracaso. Esto engendra lo que es esencialmente una actitud instrumental en el corazón de la relación de crianza. El reconocimiento se convierte en aprobación para el desempeño, en lugar de una apreciación desinteresada del crecimiento de otra persona.

Hay, por supuesto, muchas variedades de la actitud instrumental que no son denunciadas por la dependencia emocional manifiesta. Por ejemplo, la constante inquietud y la preocupación económica o las normas morales presentes en los celos o el temor a la opinión de la comunidad erosionan el desinterés maternal. Los padres son incapaces de tolerar una variedad de actos diferenciadores del niño, tales como comportamiento agresivo o exploratorio, ruidos fuertes o suciedad. Pero hoy estamos asistiendo probablemente a un mayor grado de aislamiento social entre familias e individuos, y, en consecuencia, a una díada madre-hijo más intensamente cargada que en períodos anteriores. El aislamiento y la intensidad de la relación hacen más vulnerable a la madre frente a su niño y frente a la difusión de los estándares

\footnotetext{
38 Pienso que Dinnerstein, quien sugiere con toda razón la medida en que el poder materno sobre la vida y la muerte es resentido por el niño y por todos los varones, descuida el grado en que al ejercer su propia autonomía la propia desventaja de la madre podría resentir al uso del poder materno.
} 
de funcionamiento y de éxito a través de los medios de comunicación impersonales. Hay menos baluartes personales contra el ataque de la cultura instrumental ${ }^{39}$. Sugiero que hoy en día esta tendencia hacia la aprobación individual y este desempeño en la socialización anclan firmemente la diferenciación racional o diferenciación falsa.

La tendencia hacia la racionalidad en nuestra cultura tiene una serie de consecuencias importantes. Irónicamente, la privatización doméstica parece alentar nuevas y extrañas formas colectivas de violación. La secularización de la sociedad ha erosionado muchas de las formas preexistentes de vida comunal que permitian la trascendencia ritual. La experiencia de perder el yo, de continuidad, es cada vez más difícil de obtener, excepto en la relación erótica. En consecuencia, el erotismo sexual se ha convertido en el heredero del erotismo religioso. El masoquismo o la sumisión erótica expresa la misma necesidad de trascendencia del yo: la misma huida de la separación y la discontinuidad, antes satisfechas y expresadas por la religión. El amor es la nueva religión, y los componentes psicológicos de la dominación erótica se repiten en la erotizada política de culto de nuestra era.

Creo que nos enfrentamos a una privatización y una discontinuidad insoportablemente intensificadas, sin estar aliviadas por las expresiones de continuidad. Dado que la estructura social y la cultura instrumental imponen tan rígidamente el aislamiento individual, la transgresión que intenta romperlo puede ser aún más violenta. El aumento de la violencia estetizada y erotizada en nuestros medios de comunicación (retorno de lo reprimido) sugiere la falacia de control y autocontrol en nuestra comprensión ordinaria. Cuanto más rígido y tenaz sea el límite entre los individuos, y cuanto más responsable sea cada individuo de mantenerlo, mayor será el peligro de que se derrumbe. Si el sentido de frontera se establece por la separación física, corporal, entonces la

\footnotetext{
${ }^{39}$ Barbara Ehrenreich and Deirdre English, For Her Own Good: 150 Years of the Experts' Advice to Women (Garden City, N.J.: Doubleday, 1978), es una reciente contribución importante al estudio de cómo las normas instrumentales y universales en torno al desempeño se imponen a las mujeres en su calidad de madres. Véase también mi artículo "Authority and the Family Revisited"; y Sara Ruddick, "Maternal Thinking," Feminist Studies (próximo).
} 
violencia sexual y física ( $\mathrm{si}$ no en la realidad al menos en la fantasía) se experimentan como formas de romper la frontera. La fantasía, así como el juego de la violencia racional, ofrece una forma controlada de trascendencia, la promesa de la cosa real. Las imágenes sadomasoquistas pueden ser populares porque encarnan esta promesa de trascendencia sin su temible realidad. De manera similar, si los masoquistas superan con mucho a los sádicos ${ }^{40}$, puede ser porque la gente está huyendo de la discontinuidad y la racionalidad especialmente los varones acusados de mantenerla. El rechazo de la racionalidad masculina y el control de los varones, puesto que representa una tensión intolerable, se ha convertido al menos en algo pensable.

Bajo el sensacionalismo del poder y la impotencia, el anhelo de reconocimiento -conocer y ser conocido- se adormece, no se cumple. La verdadera trascendencia, he argumentado, implica que las personas sean capaces de alcanzar una totalidad en la que se combinan los impulsos opuestos para el reconocimiento y la diferenciación. Los orígenes psicológicos de la dominación erótica pueden rastrearse en una diferenciación unilateral, es decir, a la división de estos impulsos y su asignación a mujeres y varones, respectivamente. De hecho, todas las formas de distinción de género y de dominación en nuestra cultura llevan la marca de esta división. No concluiría que las cuestiones de diferenciación y reconocimiento son la explicación de la dominación de género, sino que ayudan a revelar algunos de sus funcionamientos internos.

Aunque quisiera evitar implicar la causalidad y reconocer la naturaleza especulativa de mi análisis, creo que los paralelismos entre la violencia racional $\mathrm{y}$ otras formas de racionalidad destructiva, que han sido identificados en nuestra cultura, son demasiado llamativos para ser ignorados. Lo mismo ocurre con los paralelismos entre el modelo de dominación que Hegel bosquejó en su discusión sobre la dependencia en la relación amo-esclavo y el

\footnotetext{
${ }^{40}$ Gayle Rubin (en conversación personal) ha sugerido, sobre la base de su investigación de campo y las discusiones en la prensa masculina homosexual, que los masoquistas superan con mucho a los sádicos.
} 
sadomasoquismo descrito en La historia de ' $O$ '. La historia ilustra maravillosamente cómo la suposición masculina de dominio está vinculada a la división de la diferenciación del reconocimiento, a la racionalidad y a la violencia. Por lo tanto, parece seguro decir que los mismos problemas psicológicos corren a través de formas políticas y eróticas de dominación, ya que ambos encarnan una negación del otro sujeto. Políticamente hablando, estamos ante el agotamiento de la racionalidad masculina y el resurgimiento de la fantasía erótica. Una política que niega estas cuestiones, que trata de sanear o racionalizar los componentes eróticos y fantasmáticos de la vida humana, no derrotará a la dominación, sino que sólo jugará en ella. El poder de una fantasía, la fantasía de la violencia racional, debe atribuirse a la interacción de grandes fuerzas sociales y profundas necesidades humanas. Encontrar los medios para disolver esa fantasía, para tolerar la tensión entre la verdadera diferenciación y el reconocimiento mutuo, no será un logro fácil. 